\title{
VALUE-ADDED TAX REFORM AFTER 35 YEARS
}

\author{
Cevdet ALKIŞ ${ }^{1}$
}

\begin{abstract}
To build a strong financial structure, it is necessary to have natural resources or industrialization and also a fair tax system. Tax policy is the first priority for Turkey. The Value Added Tax (VAT), which entered into force on 1 January 1985 , has been converted into a system where the minimum tax is paid to the treasury with the help of the self-employed persons who are generally given the public power. The state did not have to settle for it. In 35 years it is necessary to abandon the system which cannot result in economic efficiency. In the new method, final consumption expenditures and taxes on imports are directly paid to the Treasury without any reimbursement or reductions. In addition to the reform, use of counterfeit documents in the sector will end, 1\% The state's right to buy will prevent leaks in the sector and the public will be relieved when the tax rate drops. External credit demand and import activity will decrease, national production and exports will increase, value added tax will be added to income and corporate tax base and the system will be simplified. With this new method, the budget deficit will close, with some 70.000.000.000 Turkish Lira additional funding, some other social projects will be easier to implement.
\end{abstract}

Keywords: Inward value added tax, foreign debt, budget deficit.

JEL Code: H3O, H25, H26

\section{Introduction}

The Value Added Tax Law, which came into force on January 1, 1985, instead of eight indirect taxes, has not undergone any radical innovation to date as a law with a discount and reimbursement system that imposes taxes on economic activities at all levels. The lack of automatic control mechanisms and improper efforts of the participants have eroded the tax payment system. Taxpayers pay only as much as they want, and the State accepts the declared tax.

The subject of the reform is the Value Added Tax.

With the reform, the automatic security method added to the system reduces the tax burden on people, reduces smuggling, import and external borrowing, and the use of counterfeit documents in the sector ends. The reform removes the tax refund mechanism and economic activities are taxed only once in the final consumption phase.

With the reform, about seventy billion Lira, which are abducted by various methods every year, will enter the Treasury directly, national production will increase and the targeted export levels will be easily reached.

Since the budget deficit will decrease, the requirements of being a social state will be fulfilled effectively.

\footnotetext{
1 Internal Auditor, University Of Akdeniz, cevdetalkis@akdeniz.edu.tr
} 


\section{Expression Of Value Added Tax Reform}

\subsection{Risks of Existing System}

In the current Value Added Tax practice, a significant portion of the tax to be transferred to the treasury is reduce by using fraudulent methods from production to final consumption until it reaches the treasury. Many taxpayers do not pay VAT to the Treasury. The state is just watching. Some of the methods used in corruption. "Counterfeit inventory, counterfeit billing, accounting fraud, merger, insufficient control, gaps in the law, etc."

\subsection{Examples of tax losses and Leaks}

\subsubsection{Tax Loss In ConstructionContracting}

While the real selling price is 650.000 Turkish Lira, there is a sales transaction which is shown as 410.000 Turkish Lira in the records. When all calculations related to cost and profit margin are made. The loss of the value added tax of the treasury reached 75.840 Turkish Lira when the tax rebate and rejection were made. The calculations detailed in Table 1 are explained in the full text of the report.

Table 1. Tax loss of the treasury according to real and low sales prices.

\begin{tabular}{|l|c|r|r|r|}
\hline Sales price / According to recordings & \multicolumn{1}{|c|}{ " } & 650.000 & 410.000 & Türkish Lira \\
\hline & & & & \\
\hline Corporate Tax & $20 \%$ & 59.200 & 12.160 & \\
\hline Value Added Tax after discount & $8 \%$ & 16.000 & -3.200 & - (tax refund) \\
\hline Buyer and seller tax fees & $4 \%$ & 26.000 & 16.400 & \\
\hline Total treasury income & & 101.200 & 25.360 & \\
\hline Tax loss of the Treasury & & & & $\mathbf{7 5 . 8 4 0}$ \\
\hline
\end{tabular}

Reference: Interbank Card Center. (2016). Statistics, https://bkm.com.tr/raporlar-ve-yayinlar/donemsel-bilgiler/

\subsubsection{Public construction tenders and tax loss}

In a construction contract, the value added tax paid by the government to the contractor is 270.000.000 TL. Most of the inputs of the contractor have labor costs that are not subject to Value Added Tax. In order to deduct tax, the service procurement method is used for labor cost. An additional tax record is made through a weak staff. Since there is a Value Added Tax on the invoice, tax is deducted from the discount. Also used be fraudulent documents. Thus, a significant portion of the Value Added Tax is not paid to the treasury.

\subsubsection{Taxpayers engaged in wholesale trade and loss of Value Added Tax.}

The annual income of a taxpayer is 10.912.000 Turkish Lira. The calculated value added tax is 1.964.000 Turkish Lira. Following the discount, TL 6.178 was paid to the Treasury. Even with $15 \%$ profitability, the tax to be calculated for value added appears to be $256.140 \mathrm{TL}$ and it 
is understood that the tax to be transferred to the Treasury has been subject to fraudulent reduce.

In smuggling, some of the methods such as "counterfeit inventory, counterfeit invoices, accounting fraud, merger, insufficient control, gaps in laws, double taxpayer, etc", were be used (Tax office declarations, 2016).

\subsubsection{Declaration of a taxpayer operating in the service sector and Value Added Tax Loss}

The one annual income of a taxpayer is 1.295.000 Türkish Lira. Calculated Value Added Tax is 233.100 Turkish Lira. Value added tax must be paid to the treasury as the main part of the inputs is not subject to the value added tax and the discount will be lower. However, due to the fraudulent practices allowed by the discount method, Value Added Tax has been lost in the way of the Treasury (Tax office declarations, 2016).

\subsection{Some Definitions, Operations to be subject to Value Added Tax / Consumption Tax and Operations not to be subject to Value Added Tax.}

In the reform, economic activities, which will be subject to taxation and which are not subject to taxation, are included in the full text of the communiqué.

2.4. Calculating the Percentage of Taxed of Credit Card Expenditures at 4-Day Festival and Calculating the Internal Percentage of Income.

Table 2. Sector based credit card payment and rates by sectors.

$\left.\begin{array}{|l|r|r|}\hline \begin{array}{l}\text { Payments made by credit } \\ \text { card on sectoral basis }\end{array} & \begin{array}{l}\text { 2016 sacrifice day } \\ \text { (12-15 September) }\end{array} & \text { (Türkish Lira) }\end{array}\right)$

Referance: Interbank Card Center. (2016). Statistics.

As seen in the table, the 4-day holiday income is 2.7 billion TL. $37 \%(496+299+214)$ is subject to low tax rate. $63 \%(420+181+1.090)$ is subject to $18 \%$ Value Added Tax.

The internal percentage is taken into account in the calculation.In other calculations other than credit card expenditures, the general tax rate was applied to $65 \%$ of the total expenditure and the low tax rate to $35 \%$ of the total expenditure. The minimum tax rate is calculated as $4.5 \%$. 


\section{Calculations and Testing of Value Added Tax Reform}

In order to see the results of the reform aiming at taxation during the final consumption, it is necessary to know the amount of the local gross national product, which is considered to be the final consumption and which is ready for one year consumption.

In the calculation of 2016 "Revenue Administration annual report, Turkey Statistical Institute, Interbank Card Center, Central Bank, Ministry annual reports and other regulatory data" is used.

In the first calculation, after obtaining only preliminary data for annual credit card income, the non-taxable parts of the annual Gross National Product are to deducted in the second been calculation.

After calculating the income of the last consumption, the annual winnings of taxable final consumption will be calculated by adding minimum earnings to the remaining amounts.

Value added tax, \% 65 - \% 35 is calculated according to the final consumption taking into consideration the income sharing rates.

Thirdly, the final calculation has been made considering the actual sales, annual credit card, real estate sales, state investment amount, local administrations and private sector investment amounts.

Our accounts were tested with one year consumption value and compared with the budget data (Interbank Card Center, 2016).

\subsection{Calculation of Value Added Tax, which will only come from the annual credit card expenditures}

Table 3. Value Added Tax Calculation table, which will only come from the annual credit card expenditures

\begin{tabular}{|c|c|c|c|c|c|}
\hline $\begin{array}{c}\text { Expenditures } \\
\text { made by Credit } \\
\text { Card in } 2016 \\
\text { (Billion Türkish } \\
\text { Lira) } \\
\text { [1] }\end{array}$ & $\begin{array}{l}37 \% \text { of this } \\
\text { amoun [1] } \\
\text { (Billion Türkish } \\
\text { Lira) }\end{array}$ & $\begin{array}{l}\text { Average of } 1 \% \text { to } \\
8 \% \text { Ratio ie } \% 4,5 \\
\text { Value Added Tax } \\
\text { [2] (internal ercentage) } \\
\text { (Billion Türkish Lira) }\end{array}$ & $\begin{array}{l}63 \% \text { Of tis } \\
\text { amount [1] } \\
\text { (Billion Türkish } \\
\text { Lira) } \\
{[4]}\end{array}$ & $\begin{array}{l}18 \% \text { Value } \\
\text { Added Tax } \\
\text { Internal } \\
\text { percentage [4] } \\
\text { (Billion Trkih L.) } \\
\text { [5] }\end{array}$ & $\begin{array}{l}\text { The sum of } \\
\text { domestic VAT } \\
\text { (Billion Türkish Lira) } \\
{[3+5],}\end{array}$ \\
\hline 652 & 241 & 10,3 & 411 & 63 & 73 \\
\hline
\end{tabular}

As it can be seen in the table, only the value of the tax that is calculated from the annual credit card revenu and will be transferred to the treasury is 73.000.000.000 Turkish Lira (Interbank Card Center, 2016 Statistics).

3.2. The calculation of the gross domestic product, which is defined as the value of the final consumption, after the separation of the non-taxable items and after the calculation.

In 2016, gross domestic product is 2.590.000.000.000 Turkish Liras and it can be defined as ready to use value. However, there are elements that are not subject to Value Added Tax. Imports are subject to separate tax, export is tax exempt. There are other exceptions. 
Savings of state receivables, savings of personnel expenses and savings ofcurrent transfers cannot enter the system in the same year. The saving part is calculated and kept separate from the one-year default value.

Savings, after separation, the final consumption value is found, Value Added Tax is calculated once. Accordingly, the Value Added Tax required to be paid to the Treasury is calculated in Table 4-5 and compared with the amount entered in the budget in the current system.

Table 4. From GDP, decomposition table of non-taxable proceeds.

\begin{tabular}{|l|r|}
\hline & Türkish Lira \\
\hline Domestic Gross National Product & 2.590 .000 .000 .000 \\
\hline Sum of non-taxable values & 1.339 .000 .000 .000 \\
\hline Taxable values & 1.251 .000 .000 .000 \\
\hline $10 \%$ minimum profit added values & 1.376 .000 .000 .000 \\
\hline$\% 65$ of \% 18 Value Added Tax & 161.000 .000 .000 \\
\hline$\% 35$ of \% 4.5 Value Added Tax & 22.000 .000 .000 \\
\hline Calculated Value Added Tax sum & 183.000 .000 .000 \\
\hline 2016 Domestic Value Added Tax & 92.000 .000 .000 \\
\hline The difference in treasury income. Domestic Value Added Tax & 91.000 .000 .000 \\
\hline
\end{tabular}

Reference: Turkish Statistical Institute. (2016) Export, Import, New Residence Sale, Revenue Administration; (2016) Activity Report and budget data

As the table shows, it is possible to obtain a maximum of try 91.000 .000 .000 of additional treasury income per year according to the calculation made on the value available for annual consumption.

This amount is 63.000 .000 .000 Turkish Lira even when the general rate is reduced to $15 \%$. 
3.3. Calculation and Testing by taking into account the annual credit card sales, countrywide residential sales, state investment amount, local administrations and private sector investments.

Table 5. Amount of value added tax calculated according to the data

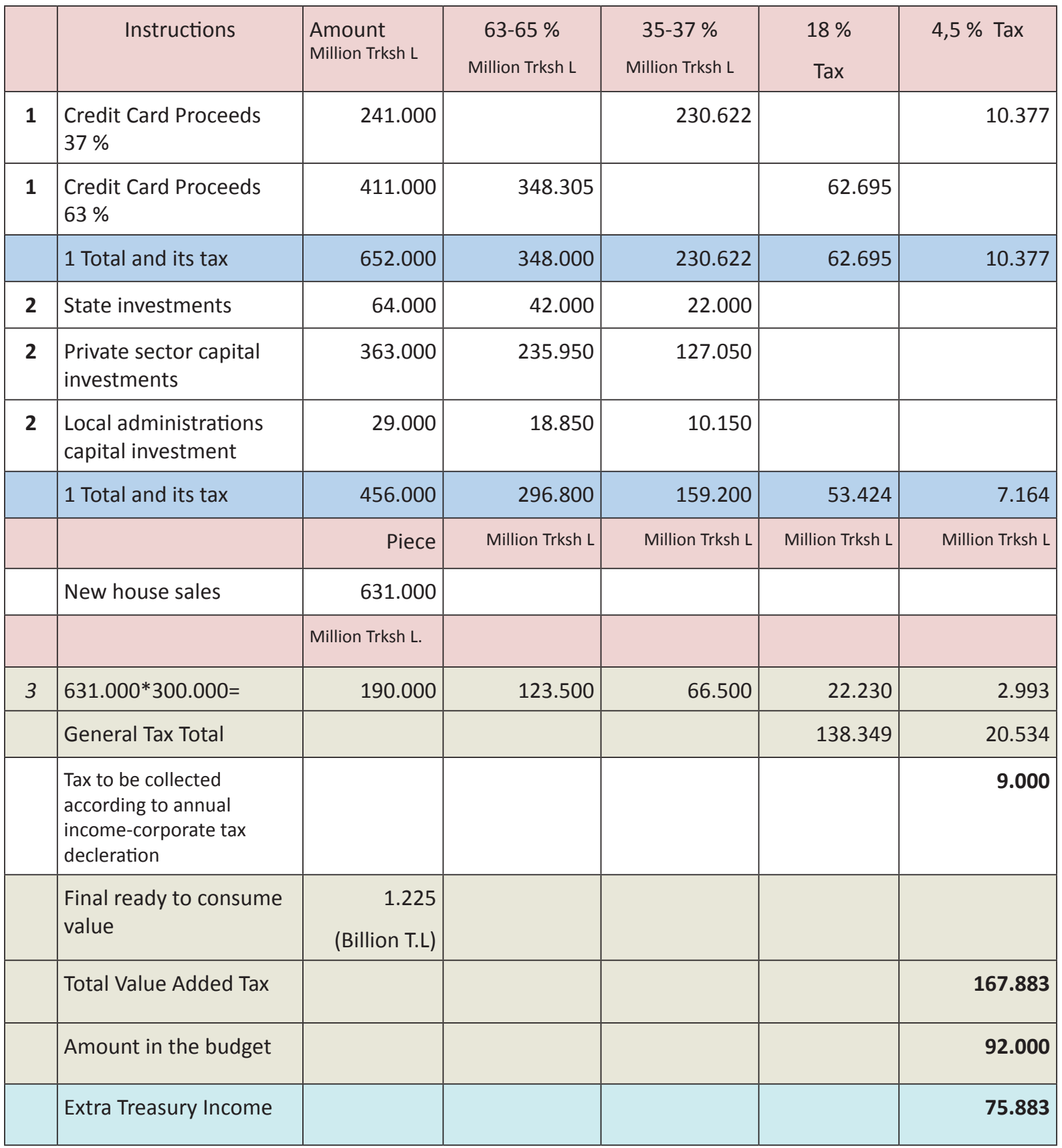

Reference: Interbank Card Center. (2016) Statistics, Ministry of Environment and Urbanization. (2016). Construction $\mathrm{M}^{2}$ Costs, Revenue Administration. (2016) Annual Report and Budget Data, Central Bank. (2016) Exchange Rates, General Directorate of Accounting. (2016) Budget Realizations, Turkey Statistical Institute. (2016) Export Import and Annual New House Sales T.L "Turkish Lira" 
As calculated in Table 6;

In cases where many other income components are not taken into consideration, the Annual Value Added Tax to be added to the Treasury $(138,349$ 20,534 = 159 9-92 = 76,000,000,000 Turkish Lira).

Even if the general rate is $15 \%$, the annual additional treasury income $(18 \%$ revenue $767 * 3=$ 23 Billion), (76-23-2 =) 51,000,000,000 Turkish Lira.

When we get the average of the data obtained as a result of the calculations based on different data and ratios, as in Table 6.

Table 6. Table of the average additional resources obtained

\begin{tabular}{|l|c|c|}
\hline Section & $\begin{array}{c}\text { According to General Ratio of 18\% } \\
\text { (Billion Türkish Lira) }\end{array}$ & $\begin{array}{c}\text { According to General Ratio of 15\% } \\
\text { (Billion Türkish Lira) }\end{array}$ \\
\hline 3.1. Table 2 & 91 & 65 \\
\hline 3.3. Table 3 & 76 & 51 \\
\hline Average ( Approximate) & 83 & 58 \\
\hline$\sim$ General average & $(83+58) / 2=$ & 70 \\
\hline
\end{tabular}

As can be seen in Table 7, the annual average of additional treasury income can be calculated as approximately 70.000.000.000 Turkish Liras.

\subsection{Calculation of Value Added Tax over annual declarations of taxpayers.}

In the reform, the taxpayers' annually declared income will be subject to additional value added tax / consumption tax.

Tax is calculated as shown in Table 7.

Table 7- "Value Added Tax / Consumption Tax" calculation table from tax basis on Annual Income Tax , Corporate Tax

\begin{tabular}{|l|r|r|r|}
\hline Taxes except advance tax and deduction & & (Türkish Lira) & 10.090 .000 .000 \\
\hline $\begin{array}{l}\text { Calculation of tax basis from 20\% of tax } \\
\text { “ }\end{array}$ & $10.090 \times 100 / 20$ & (Türkish Lira) & 50.450 .000 .000 \\
\hline Value Added Tax Calculation & $50.450 \times 18 / 100$ & (Türkish Lira) & 9.000 .000 .000 \\
\hline
\end{tabular}

Reference: Revenue Administration presidency (2016) budget data.

\subsection{Penalty practice}

Value Added Tax / Consumption Tax, which is determined not to be deposited in the Treasury, shall be collected with a three-fold penalty without any discount.

(Article 359 shall not be considered a crime. In our reform, the Article 359 will be reorganized with the logic of material punishment for material crime.) 


\subsection{Transfer to the next period and the application of value added tax}

When the reform is realized, taxpayers will dissolve their, Deferred Value Added Tax in their stocks within 5-10 years according to the law to be enacted.

\subsection{Generating Automatic Control Mechanism}

Placed in the system,

The method, which gives the state the right to buy $1 \%$ extra, will provide the real price in the real estate market.

\subsection{The Concept of Tax to be used in Reform}

Since the value added tax is already taxed at the end of the final consumption, the term to be used may be the Value-Added Tax (VAT), and this term may also be used in the Law and in the literature as a Consumption Tax (CT).

\section{Conclusion}

With the reform, the method by which the value added tax calculated after the discount is paid to the treasury is removed. Value Added Tax return method is removed. Only economic activities at the final consumption stage will be taxed once.

The value added tax / excise tax collected shall paid directly to the treasury.

Furthermore;

- It is aimed to prevent smuggling of immovable sales prices by means of automatic control that provides the right to purchase to the state.

The state's right to purchase can be set as $1 \%$ added and as upper limit.

- Value added tax / consumption tax shall be applied to the income tax and corporate tax base declared with annual declaration.

This application is done in addition.

- Legislation and exceptions will be simplified.

- As import continues to be taxable, tax (VAT-CT) is recorded as cost.

- When the tax is found not to be paid to the treasury, the tax and three-fold tax penalty shall be as collected.

- The distorted system in external debt formation will be eliminated and exports will be encouraged as national production increases.

- The use of counterfeit bills will be reduced by $95 \%$.

- The $18 \%$ general tax rate of VAT will be reduced.

- When reform is made, taxpayers can write the value added tax transferred from old years as expense within 5-10 years. 
- There will be a simple, fairer control method. This will create awareness for taxpayers.

- Tax will not be transferred to other areas by illegal methods.

- When E is supported by accounting and e-billing systems, centralized audit will be easier and audit rates will be increased.

- Most importantly, approximately 70.000.000.000 Turkish Lira additional treasury income will facilitate the implementation of other public projects and budget deficit will be minimum.

\section{References}

Alkış, C. (2018). "Kamu Yönetiminde Riskli İşlemler ve Hukuka Uygun Yöntemleri”, 1. Baskı, Antalya: University Of Akdeniz Publications, http://icdenetim.akdeniz.edu.tr/yayinlarimiz.

Interbank Card Center. (2016). Statistics, https://bkm.com.tr/raporlar-ve-yayinlar/donemselbilgiler/ (02.02.2018).

Ministry Of Environment Urbanization. (2016). M2 Construction Costs, http://www.dkbb.gov.tr/ $? p=4276 /(04.02 .2019)$.

President Of Revenue Administration. (2016). Annual Report, http://www.gib.gov.tr/ kurumsal/stratejik-yonetim /, (04.07.2018).

The Central Bank. (2016). Foreign Exchange Rates, http://www.tcmb.gov.tr/ kurlar/kur2016_tr.html, (01.02.2019).

Turkish Statistical Institute. (2016). Export Import and annual sale of new housing, http://tuik. gov.tr/Start.do / (02.02.2018).

Value Added Tax Law No. 3065. http://www.mevzuat.gov.tr/Kanunlar.aspx / (02.02.2018). 